Acta vet. scand. $1978,19,422-429$.

From the Department of Pharmacology and Toxicology, Veterinary College of Norway, Oslo, the National Veterinary Institute, Oslo and the Institute of Occupational Health, Oslo, Norway.

\title{
THE MOBILIZATION OF COPPER IN SHEEP BY CHELATING AGENTS
}

\author{
By \\ Nils E. Sфli, Arne Frфslie and Jan Aaseth
}

SØLI, N. E., A. FRøSLIE and J. AASETH: The mobilization of copper in sheep by chelating agents. Acta vet. scand. 1978, 19, 422429. - D-penicillamine and 2,3-dimercapto-propane-1-sulphonate (DMPS) were administered orally and disodium-calcium-ethylenediamine-tetraacetate (Ca-EDTA) subcutaneously into copper loaded sheep. The results showed that $D$-penicillamine has a copper mobilizing effect, while DMPS and Ca-EDTA do not seem to have this effect to any significant degree. Penicillamine, $52 \mathrm{mg} / \mathrm{kg}$ of body weight daily for 6 days, increased the urinary excretion of copper by a factor of 10 to 20. The same dosage (on weight basis) of DMPS increased the excretion of copper in urine by 2 fold. Following Ca-EDTA treatment no increase in urinary excretion of copper was observed. Penicillamine could be used in prophylactic treatment of copper toxicosis in sheep, but it is still too expensive for practical use.

copper; chelating agents; excretion; sheep.

Sheep are extremely sentitive to excess of copper in the feed and can accumulate large amounts of copper in the liver (Underwood 1977).

Molybdenum and sulphate are useful agents in preventing copper retention in sheep, and zinc has also proved to be an active metabolic antagonist to copper (Underwood).

Synthetic chelators are of interest as possible prophylactic or therapeutic agents in sheep. The traditional chelating agent, 2,3-dimercapto-1-propanol (BAL), however, does not increase the excretion of copper in the urine of affected sheep (Clarke $\&$ Clarke 1975). Its derivative, 2,3-dimercapto-propane-1-sulphonate, is reported to mobilize $\mathrm{Hg}^{++}$effectively in rats (Gabard $1976 a)$, but has not been studied with respect to mobilization of $\mathrm{Cu}^{++}$. 
In the present investigation the copper mobilizing effect of this sulphonated derivative is compared with the effects of CaEDTA and penicillamine, the latter agent being the currently used therapeutic in Wilson's disease in man.

\section{MATERIALS AND METHODS \\ Experimental animals}

The experiments were carried out on 61 -year-old ewes of Norwegian Dala breed weighing from 35 to $52 \mathrm{~kg}$. The sheep were in a condition of copper loading, as they had been fed $20 \mathrm{mg}$ $\mathrm{CuSO}_{4} \cdot 5 \mathrm{H}_{2} \mathrm{O} / \mathrm{kg}$ of body weight daily for 5 weeks. After the copper dosing was ended, the sheep were kept on water and hay for 2 weeks before and throughout the experiment. The hay and water contained $3.6 \mu \mathrm{g} / \mathrm{g}$ and $0.28 \mu \mathrm{g} / \mathrm{ml}$ copper and $0.22 \mu \mathrm{g} / \mathrm{g}$ and $0.001 \mu \mathrm{g} / \mathrm{ml}$ molybdenum, respectively, as determined by activation analysis. In addition, 1 ewe weighing $42 \mathrm{~kg}$, which had turned into the terminal haemolytic crisis of spontaneous copper toxicosis, was also used in an excretion experiment.

The sheep were tied up in metabolism stalls, and urine was collected through permanent bladder catheters (Folaflate balloon catheter) for copper analysis. Blood samples collected at given intervals before and during the experimental period were analyzed for plasma copper. For clinical control purposes, the blood samles were also analyzed for some haematological and enzymatic parameters, but these results will not be reported.

At the end of the experiments, the animals were killed and necropsies were carried out. Samples of liver tissue were submitted to copper analysis.

\section{Analytical methods}

Plasma copper was determined by atomic absorption spectroscopy after dilution with distilled water. Liver and urine copper concentrations were determined by the same method after wet digestion of the samples with sulphuric-, nitric- and perchloric acid.

\section{Drugs}

D-penicillamine (Cuprimine $\AA$, capsules containing $250 \mathrm{mg}$, Merck - Sharp \& Dohme) was dosed orally to sheep Nos. 1 and 2 twice a day at a rate of $52 \mathrm{mg} / \mathrm{kg}$ of body weight daily for 6 days. 
2,3-dimercapto-propane-1-sulphonate (DMPS, capsules containing $140 \mathrm{mg}$, Heyl \& Co., Berlin) was given to sheep Nos. 3 and 4 at the same dosage (on weight basis) and period of time as mentioned for penicillamine.

Disodium-calcium-ethylenediamine-tetraacetate (Ca-EDTA, Merck) was injected subcutaneously into sheep Nos. 5 and 6 as a $1 \%$ solution in $5 \%$ glucose at a rate of $110 \mathrm{mg} / \mathrm{kg}$ of body weight twice a day for 2 days. Sheep No. 7 was injected the CaEDTA solution intravenously by drop infusion at a rate of $1 \mathrm{mg}$ Ca-EDTA $/ \mathrm{kg} / \mathrm{hr}$. for $29 \mathrm{hrs}$. The infusion was started by an initial injection of $60 \mathrm{mg} / \mathrm{kg}$ of body weight.

\section{Penicillamine}

\section{RESULTS}

The results of the penicillamine dosage on the copper excretion in urine are illustrated in Fig. 1. In both ewes, the copper excretion was increased by a factor of 10 to 20 . The increased excretion started 1 day after the first dosage, and the maximum effect occurred after 2 to 3 days. When the treatment was interrupted, the excretion rate immediately decreased again.

Sheep No. 1 had a significantly higher copper excretion than the other experimental animals both before, during and after dosage. This was considered to be a result of a slight elevation of the plasma copper indicative of a moderate copper release from the liver.

\section{DMPS}

The urinary excretion of copper after the dosage of DMPS is illustrated in Fig. 1. Compared to the effect of penicillamine, the increase of the copper excretion was much smaller, as there was only a 2- to 3-fold increase.

\section{Ca-EDTA}

The effect of Ca-EDTA on the excretion of copper is illustrated in Fig. 2. As seen from the figure, the treatment caused no significant effect on the copper excretion in the experimental animals.

In the copper poisoned animal the plasma copper level decreased from 6 to $3 \mu \mathrm{g} / \mathrm{ml}$ during the $29 \mathrm{hrs}$. treatment period, and the urinary excretion decreased from 0.9 to $0.3 \mathrm{mg} / \mathrm{hr}$. in 


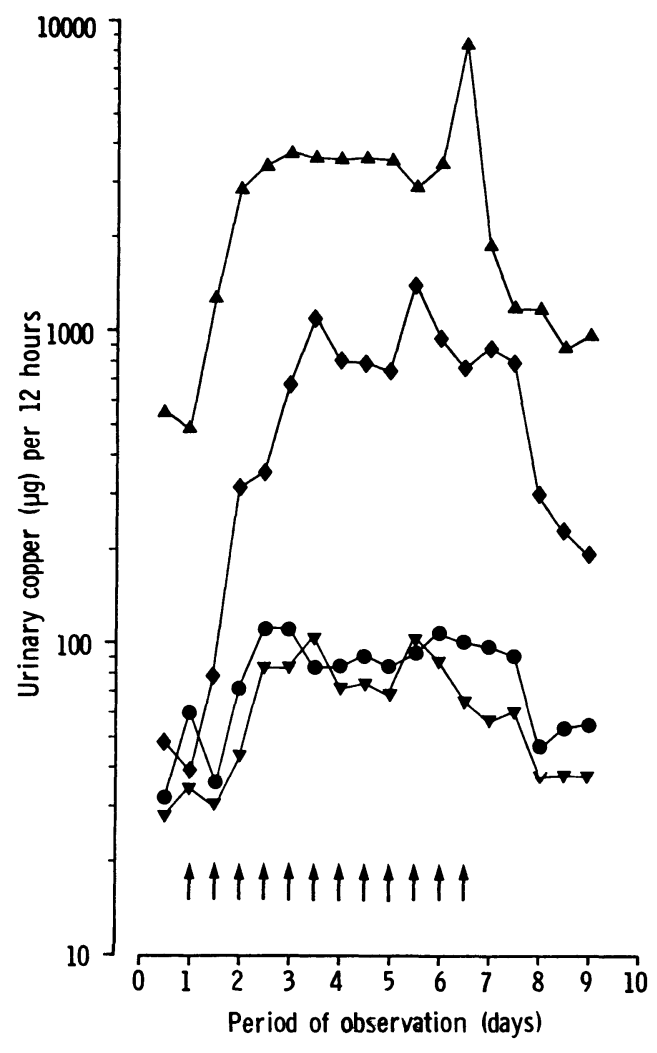

Figure 1. The urinary excretion of copper ( $\mu$ g) per $12 \mathrm{hrs}$. after oral administration to 4 sheep of the chelating agents penicillamine (Nos. 1 and 2) and DMPS (Nos. 3 and 4). Arrows indicate dosages. The dose was for both drugs 52 $\mathrm{mg} / \mathrm{kg}$ of body weight divided into 2 daily dosages for 6 days. Sheep No. 1 $\triangle \Delta$, sheep No. $2>$, sheep No. 3 $\longrightarrow$, sheep No. 4

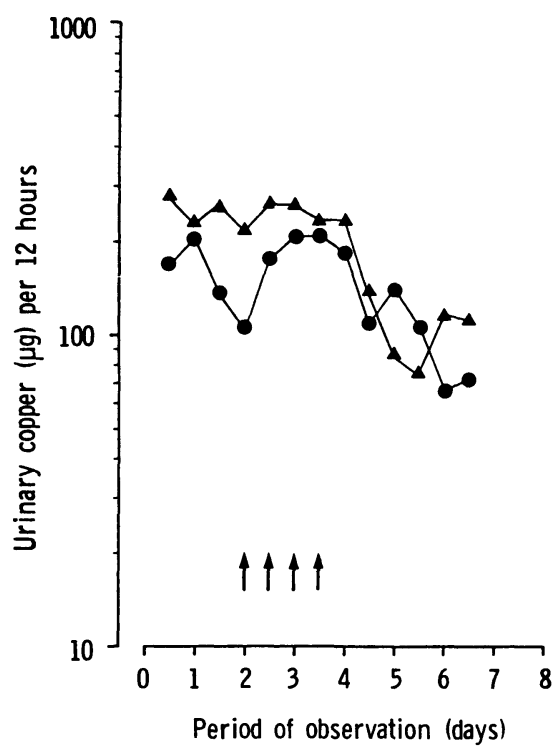

Fig u r e 2. The urinary excretion of copper ( $\mu \mathrm{g})$ per $12 \mathrm{hrs}$. after subcutaneous injection of 2 sheep with the chelating agent Ca-EDTA (Nos. 5 and 6). Arrows indicate injections. The animals were given $110 \mathrm{mg} / \mathrm{kg}$ of body weight twice daily for 2 days. Sheep No. 5 $\triangle-\triangle$, sheep No. $6 \bullet-\bullet$.

the same period. The sheep died 29 hrs. after the start of the treatment.

Sheep Nos. 5 and 6 developed an anorexia the last day of the treatment and did not recover during the observation period.

Clinical and post-mortem findings

The mean diuresis varied from 12 to $24 \mathrm{ml} / \mathrm{kg} / \mathrm{day}$ for the ewes with exception of the sheep suffering from the terminal 
haemolytic crisis. This particular sheep had a diuresis of $\mathbf{1 3 0}$ $\mathrm{ml} / \mathrm{kg} /$ day.

With the exception of sheep Nos. 1 and 7, the plasma copper concentrations were within normal ranges $(0.8-1.2 \mu \mathrm{g} \mathrm{Cu} / \mathrm{ml})$, and no particular pathological changes were observed by postmortem examination. Sheep No. 1 had increased plasma copper concentrations (up to $1.6 \mu \mathrm{g} / \mathrm{ml}$ ) at the beginning of the experiment, but the concentration normalized during the experimental period. Clinical symptoms, expressed by moderate elevation of plasma glutamic oxaloacetic transaminase (GOT) and a tendency to haemoconcentration, were also observed in this particular sheep, and at necropsy scattered focal liver necroses of minor degree were observed by histological examination. Sheep No. 7, which suffered from a terminal haemolytic crisis following a spontaneous copper toxicosis, showed clinical and pathological changes in accordance with the alterations usually found in copper toxicosis. The copper concentrations in the liver tissues of the ewes at necropsy, are given in Table 1.

Table 1. Post-mortem concentrations of copper in the liver of the ewes.

\begin{tabular}{lc}
\hline $\begin{array}{c}\text { Sheep } \\
\text { No. }\end{array}$ & $\begin{array}{c}\text { Copper concentrations } \\
(\mathbf{m g} / \mathbf{k g} \text { wet weight })\end{array}$ \\
\hline 1 & 575 \\
2 & 280 \\
3 & 290 \\
4 & 400 \\
5 & 265 \\
6 & 420 \\
7 & 510 \\
\hline
\end{tabular}

\section{DISCUSSION}

The results of the present investigation clearly demonstrate that penicillamine increases the excretion of copper in sheep. DMPS and Ca-EDTA, on the other hand, do not seem to have this effect to any significant degree.

Considering the mode of action of orally administered chelating agents, 3 possibilities exist. First, copper excreted to the gastrointestinal tract may form a complex with the agent in the gut, and this complex may subsequently be excreted. Since the 
total excretion of copper to the gastrointestinal tract in sheep seems to be low (Søli \& Rambæk 1978), it is supposed that this mode of action is of minor importance in sheep.

Secondly, the chelating agent may be absorbed as such from the gastrointestinal tract and may react with copper in the blood or in the extracellular space. Penicillamine and DMPS may act by this mechanism. The absorption of penicillamine is rather high, amounting to $60 \%$ (Catsch \& Harmuth-Hoene 1976). Gabard (1978) has recently examined the absorption of DMPS and found it to be about $30-40 \%$. If the difference in the absorption seen in rat is of the same magnitude in sheep, it could explain to a certain degree the difference in chelating capacity between those 2 agents seen in vivo.

The third mechanism, the intracellular complex formation, is probably of minor importance since DMPS is thought to be a non-penetrating agent, and D-penicillamine is found to penetrate the cellular membranes only to a limited extent (Catsch \& Harmuth-Hoene, Aaseth 1976).

DMPS has been found to increase the urinary excretion of mercury in rats and mice (Gabard 1976a, b, Aaseth \& Friedheim 1978), and Ca-EDTA is a well known chelator with good excretorial effects in cases of lead poisoning (Levine 1975, Hatch 1977). In vitro these 2 latter agents also have affinity to divalent copper (Ringbom 1963, Aaseth, unpublished results), they are, however, obviously far less effective than penicillamine in breaking the strong attachment between copper and its binding sites in vivo.

The anorexia of the sheep on the Ca-EDTA treatment may be related to the high dose used, as the dose chosen is at the upper limit of the tolerance. However, the dose used in the present experiment is recommended to calves and cattle suffering from lead poisoning (Hatch).

The diuresis of the experimental animals were within normal ranges (Gans 1970). The increased diuresis in sheep No. 7 was probably caused by the effect of the crisis on the kidney function and the effect of the drop infusion of Ca-EDTA.

A decrease of plasma copper similar to that seen in the sheep treated with Ca-EDTA as a drop infusion, is a characteristic finding in the terminal haemolytic crisis of copper poisoning (Sфli \& Frøslie 1977).

The difference in copper concentrations in the livers is as- 
sumed to originate from variations in liver copper concentrations before the treatment, and should probably not be ascribed to the effect of the chelating agents. The copper concentrations in sheep liver usually show great variations (Frøslie \& Norheim 1976).

The positive effect of penicillamine on the copper excretion is comparable to its effect on humans suffering from Wilson's disease, to whom approximately the same dose levels are used (Levine). This agent therefore could be used in prophylactic treatment of copper toxicosis in sheep, but compared to molybdenum and sulphate supplementation, it would be rather expensive for use under practical conditions.

\section{ACKNOWLEDGEMENTS}

The determinations of copper and molybdenum concentrations in hay and water by activation analysis were carried out at Institut for Atomenergi, Isotope Laboratories, Kjeller, Norway.

Transaminase and haematological analyses were performed at the Department of Internal Medicine I, Veterinary College of Norway, Oslo.

\section{REFERENCES}

Aaseth, J.: Mobilization of methyl mercury in vivo and in vitro using $\mathrm{N}$-acetyl-DL-penicillamine and other complexing agents. Acta pharmacol. (Kbh.) 1976, 39, 289-301.

Aaseth, J. \& E. A. H. Friedheim: Treatment of methyl mercury poisoning in mice with 2,3-dimercaptosuccinic acid and other complexing thiols. Acta pharmacol. (Kbh.) 1978, 42, 248-252.

Catsch, A. \& A.-E. Harmuth-Hoene: Pharmacology and therapeutic applications of agents used in heavy metal poisoning. Pharmacol. Ther. A. 1976, 1, 1-118.

Clarke, E. G. C. \& M. L. Clarke: Veterinary Toxicology. Bailliere Tindall, London 1975, p. 62.

Frøslie, A. \& G. Norheim: The concentrations of molybdenum and zinc in liver in relation to copper accumulation in normal and copper poisoned sheep. Acta vet. scand. 1976, 17, 307-315.

Gabard, B.: The excretion and distribution of inorganic mercury in the rat as influenced by several chelating agents. Arch. Toxicol. $1976 \mathrm{a}, 35,15-24$.

Gabard, B.: Improvement of oral chelation treatment of methyl mercury poisoning in rats. Acta pharmacol. (Kbh.) 1976b, 39, 250255.

Gabard, B.: Distribution and excretion of the mercury chelating agent sodium 2,3-dimercaptopropane-1-sulfonate in the rat. Arch. Toxicol. 1978, 39, 289—298. 
Gans, J. H.: The kidneys. In Dukes Physiology of Domestic Animals. M. J. Swenson (ed.). 8th Ed., Comstock Publishing Associates 1970, 767-812.

Hatch, R. C.: Veterinary toxicology. In Veterinary Pharmacology and Therapeutics. L. Meyer Jones, N. H. Booth \& L. E. McDonald (eds.). 4th Ed., Ames, Iowa State Univ. Press 1977, 1121-1296.

Levine, W. G.: Heavy-metal antagonists. In The Pharmacological Basis of Therapeutics. L. S. Goodman \& A. Gilman (eds.). 5th Ed., Macmillan Publishing Co., Inc., New York 1975, 912-923.

Ringbom, A.: Complexation in Analytical Chemistry. Interscience Publishers, London 1963, p. 333.

$S \varnothing l i, N . E . \& A$. Frøslie: Chronic copper poisoning in sheep. I. The relationship of methaemoglobinemia to Heinz body formation and haemolysis during the terminal crisis. Acta pharmacol. (Kbh.) 1977, 40, 169-177.

$S \phi l i, N . E . \&$ J. P. Rambæk: The excretion of intravenously injected copper-64 in sheep. Acta Pharmacol. (Kbh.) 1978. In press.

Underwood, E. J.: Trace Elements in Human and Animal Nutrition. 4th Ed., Acad. Press, New York 1977, 545 pp.

\section{SAMMENDRAG}

Mobilisering av kobber hos sau ved bruk av kelatorer.

D-penicillamin og 2,3-dimercapto-propan-1-sulfonat (DMPS) ble gitt oralt og dinatrium-kalsium-etylendiamin-tetraacetat (Ca-EDTA) subcutant til kobberbelastede sauer. Resultatene viser at D-penicillamin har kobbermobiliserende effekt ved doser som tilsvarer dosering anbefalt til menneske. DMPS og Ca-EDTA synes ikke å ha denne effekten i noen særlig grad. $52 \mathrm{mg}$ penicillamin/kg kroppsvekt daglig i 6 dager $\varnothing$ kte urinutskillelsen av kobber med en faktor på 10-20. Den samme dosering (på vektbasis) av DMPS økte utskillelsen av kobber $i$ urin til det dobbelte. Etter Ca-EDTA behandling ble det ikke registrert noen $\varnothing \mathrm{kning}$ av utskillelsen av kobber $\mathrm{i}$ urinen.

Penicillamin kunne derfor tenkes brukt $i$ den profylaktiske behandling av kobber-toksikose hos sau, men sammenlignet med tilf $\emptyset \mathrm{r}$ sel av molybden og sulfat blir det for dyrt under praktiske forhold.

(Received March 8, 1978).

Reprints may be requested from: Nils E. Søli, the Department of Pharmacology and Toxicology, Veterinary College of Norway, P. O. Box 8146, Oslo Dep., Oslo 1, Norway. 